\title{
Public Procurement Procedure in Construction in Poland And Problems With its Application
}

DOI 10.5592/otmcj.2011.1.7 Research paper

\author{
Elżbieta Radziszewska-Zielina \\ Department of Construction Technology and Organization, Faculty of \\ Civil Engineering, Cracow University of Technology, Poland \\ Email: eradzisz@izwbit.pk.edu.pl
}

Public Procurement laW in Poland is applied during the ConstrucTION OF CIVIL STRUCTURES FINANCED FROM PUBLIC FUNDS. PROVISIONS RELATED TO THIS LAW OFTEN CHANGE, WHICH MAKES THEIR APPLICATION DIFFICULT.

The article describes public procurement procedures in the field of construction in Poland which is limited to two basic modes of tender. The most common mistakes made by customers related to the implementation of this procedure had also been presented.

The author analyzed procedures related to public procurement in Poland. She also met with and conducted interviews with a few representatives of Polish gminas responsible for the organization and conduct of construction tenders. The aim of these interviews was to discover problems related to the implementation of public procurement procedures and the most common mistakes that had been made. Furthermore, the author had analyzed the available tender documentation taking into account problematic documents.

The tender procedure had been clearly presented in the article in points and table listings. Aspects pertaining to problems and the reasons why mistakes had been made by customers had also been presented. These mistakes are mainly related to the subject of order, concern the conditions of participation in the proceedings and the specification of essential terms and conditions of the order. Consequences of these mistakes may be appeals and annulment of proceedings.

\section{Introduction}

In Poland, the legal basis of the tender procedure is the Act of 29th January 2004 [3], [5]. Due to the fact that the Public Procurement Law has been constantly changing, with amendments introduced practically every year, there are no manuals and guides to aid public investors in this respect. Some tenders are cancelled due to the fact that the customer has prepared a tender offer in accordance with the old regulations that have been amended, which the customer has been unaware of [1], [4]. In order to aid public sector customers as well as bidders, the present Author 
discusses two basic tender modes: an open tendering and a restricted tendering in terms of their procedures and required documents. The issue is presented in clear points and tables, which may facilitate the comparison and application of the two modes in practice. Moreover, such juxtapositions may serve as a model to compare the procedures in other countries. The lawmakers aim at standardizatoin of the public procurement regulations in the EU countries; however, certain differences do exist. In the following part of the article on the basis of conducted interviews with public customers and on the basis of the analysis of available documentation, the main problems related to the implementation of the public procurement procedure and the most common mistakes made by customers were presented.

\section{Public procurement modes}

\section{Characteristics of the basic modes}

The modes of construction work commissioning may be divided into two basic types:

\section{- the competitive bidding mode (the form of a competition, selecting the best offer), \\ - the negotiated contracting mode - a commission on a freelance basis (discussing issues together in order to achieve a common stand and sign a contract; this mode may be written or oral).}

Table 1 presents the advantages and disadvantages of the competitive bidding mode, implemented in the form of invitations to tender.

In further subchapters 2.2-2.4 the procedure for two basic public procurement modes in Poland is shown in points and in tabular form: an open tendering and a restricted tendering.

\begin{tabular}{|l|l|}
$\begin{array}{l}\text { Advantages of the competitive bidding } \\
\text { mode }\end{array}$ & $\begin{array}{l}\text { Disadvantages of the competitive bidding } \\
\text { mode }\end{array}$ \\
$\begin{array}{ll}\text { possibility to compare tenders } & \text { limited possibility to agree on details } \\
\text { smaller possibility to depart from } & \text { due to limited interpersonal contact of } \\
\text { the market reality to a customer's } & \text { the sides, or sometimes even a ban on } \\
\text { contact } & \text { large possibility of conflicts during } \\
\text { smaller possibility of an accusation of } & \text { project implementation } \\
\text { partiality } & \text { a long period of contract negotiation } \\
\text { the choice of a given contractor easily } & \text { considerable costs of proceedings } \\
\text { justified to the supervisors } & \text { on both sides (the preparation of the } \\
& \text { proceedings, the preparation of the later } \\
& \text { rejected tenders) }\end{array}$ \\
\hline
\end{tabular}

Table 1: The advantages and disadvantages of the competitive bidding mode

\section{An open tendering}

An open tendering is the mode in which, in response to a public invitation to tender, all interested contractors may submit tenders. The characteristics of the open tendering is presented in Table 2. The subsequent chapters of the Public Procurement Law often contain references to Article 11, Paragraph 8, which states that the Prime Minister deter- mines, in the form of a regulation, the financial value of commissions and competitions in relation to which there is an obligation to send announcements to the Publication Office of the European Union due to the relevant legal regulations of the European Union. The regulation currently in force, of 23th Dec. 2009, defines the above-mentioned value of construction work as 4,845,000 euros [2].

\begin{tabular}{|c|c|c|}
\hline \multicolumn{3}{|c|}{ THE OPEN TENDERING } \\
\hline Reasons to use it & always & \\
\hline Amounts & $\begin{array}{l}\text { to the amounts lower than the } \\
\text { ones defined in the regulations } \\
\text { issued on the basis of Art. 11, } \\
\text { Par. } 8\end{array}$ & $\begin{array}{l}\text { from the amounts equal or } \\
\text { higher than the ones defined in } \\
\text { the regulations issued on the } \\
\text { basis of Art. 11, Par. } 8\end{array}$ \\
\hline $\begin{array}{l}\text { The way of publication } \\
\text { of an invitation to } \\
\text { tender }\end{array}$ & $\begin{array}{l}\text { on the website of the } \\
\text { Public Procurement Office } \\
\text { - publication in the Public } \\
\text { Procurement Bulletin; } \\
\text { Moreover, on the customer's } \\
\text { own website; } \\
\text { In the customer's office in a } \\
\text { well visible place, in a daily } \\
\text { newspaper or a national } \\
\text { journal (from the date of the } \\
\text { notice publication in the Public } \\
\text { Procurement Bulletin) }\end{array}$ & $\begin{array}{l}\text { sending the notice to the } \\
\text { Publication Office of the } \\
\text { European Union - publication } \\
\text { in the Official Journal of the } \\
\text { European Union (O.J. EU) } \\
\text { Moreover, on customer's own } \\
\text { website; } \\
\text { In the customer's office in a } \\
\text { well visible place, in a daily } \\
\text { newspaper or a national journal } \\
\text { (from the date of the notice } \\
\text { publication in the O.J. EU) }\end{array}$ \\
\hline $\begin{array}{l}\text { Specification of } \\
\text { essential terms of the } \\
\text { contract }\end{array}$ & yes, prepared by the customer & yes, prepared by the customer \\
\hline $\begin{array}{l}\text { The way of allowing } \\
\text { access to the } \\
\text { specification of } \\
\text { essential terms of the } \\
\text { contract }\end{array}$ & $\begin{array}{l}\text { obligatory on the website (from } \\
\text { the date of publication of the } \\
\text { notice in the Public Procurement } \\
\text { Bulletin to the deadline for } \\
\text { tenders); } \\
\text { On the contractor's request, in } \\
\text { the written form, within } 5 \text { days }\end{array}$ & $\begin{array}{l}\text { obligatory on the website } \\
\text { (from the date of publication of } \\
\text { the notice in the O.J. EU to the } \\
\text { deadline for tenders); } \\
\text { On the contractor's request, in } \\
\text { the written form, within } 5 \text { days }\end{array}$ \\
\hline $\begin{array}{l}\text { The deadline for } \\
\text { tenders }\end{array}$ & $\begin{array}{l}\text { must not be shorter than } 14 \\
\text { days }\end{array}$ & $\begin{array}{l}\text { from the date of sending the } \\
\text { notice to the Publication Office } \\
\text { of the European Union: } \\
40 \text { days (by e-mail), } \\
47 \text { days - via other means }\end{array}$ \\
\hline A deposit & may be required & is required \\
\hline $\begin{array}{l}\text { The smallest number } \\
\text { of contractors }\end{array}$ & 1 tender not rejected & 1 tender not rejected \\
\hline
\end{tabular}

Table 2: Characteristics of the open tendering 
The tender procedure is a set of rules, known at least to the tender participants, which allow for commissioning and awarding a contract for construction work.

\section{The procedure of the open tendering is} as follows:

- invitation to tender by the customer,

- informing those contractors that the customer knows,

- expressing interest by the contractors and obtaining the tender documentation necessary for tender preparation,

- tender preparation,

- submission of tenders along with payment of a deposit (if required),

- public tender opening and giving the basic information about the tender and the bidder,

- tender validity verification by the customer,

- assessment of valid tenders,

- selecting the most profitable tender by the customer or annulment of the invitation to tender (informing all bidders about this decision),

- payment of the guarantee of proper contract fulfilment by the chosen bidder,

- contract signing (following the period allowed for possible protests or complaints).

\section{A restricted tendering}

$A$ restricted tendering is the mode in which, in response to a public invitation to tender, all interested contractors may apply to be allowed to bid and tenders are then submitted by the contractors invited to do so. The characteristics of the restricted tendering is presented in Table 3.

\section{THE RESTRICTED TENDERIBG}

\begin{tabular}{|c|c|c|}
\hline Reasons to use it & \multicolumn{2}{|l|}{ always } \\
\hline Amounts & $\begin{array}{l}\text { to the amounts lower than the } \\
\text { ones defined in the regulations } \\
\text { issued on the basis of Art. 11, } \\
\text { Par. } 8\end{array}$ & $\begin{array}{l}\text { from the amounts equal or } \\
\text { higher than the ones defined in } \\
\text { the regulations issued on the } \\
\text { basis of Art. 11, Par. } 8\end{array}$ \\
\hline $\begin{array}{l}\text { The way of } \\
\text { publication of an } \\
\text { invitation to tender }\end{array}$ & \multicolumn{2}{|l|}{ as in the open tendering } \\
\hline $\begin{array}{l}\text { The deadline for } \\
\text { applications for } \\
\text { admission to } \\
\text { participate in the } \\
\text { proceedings }\end{array}$ & $\begin{array}{l}\text { must not be shorter than } 7 \\
\text { days from the date when the } \\
\text { notice appears in the Public } \\
\text { Procurement Bulletin }\end{array}$ & $\begin{array}{l}30 \text { days (via e-mail), } \\
37 \text { days (via other means)and, } \\
\text { if urgently needed, } 10 \text { days (via } \\
\text { e-mail) or } 15 \text { days (via other } \\
\text { means) } \\
\text { from the date of sending the } \\
\text { notice to the Publication Office } \\
\text { of the European Union }\end{array}$ \\
\hline $\begin{array}{l}\text { specification of } \\
\text { essential terms of } \\
\text { the contract }\end{array}$ & $\begin{array}{l}\text { yes, together with the invitation } \\
\text { to tender }\end{array}$ & $\begin{array}{l}\text { yes, together with the invitation } \\
\text { to tender }\end{array}$ \\
\hline $\begin{array}{l}\text { The deadline for } \\
\text { tenders }\end{array}$ & $\begin{array}{l}14 \text { days from the date of } \\
\text { delivering the invitation to } \\
\text { tender }\end{array}$ & $\begin{array}{l}\text { not shoter than } 40 \text { days; } \\
\text { If urgently needed - } 10 \text { days } \\
\text { from the date of delivering the } \\
\text { invitation to tender }\end{array}$ \\
\hline A deposit & may be required & is required \\
\hline $\begin{array}{l}\text { The smallest number } \\
\text { of contractors }\end{array}$ & \multicolumn{2}{|c|}{$\begin{array}{l}\text { specified in the notice, preferred: } 5-20 \\
\text { If the number of the interested contractors is higher than } \\
\text { specified in the notice, the customer invites those contractors } \\
\text { who received the highest score for the fulfilment of conditions. If } \\
\text { their number is smaller than specified in the notice, the customer } \\
\text { invites all contractors who fulfil these conditions }\end{array}$} \\
\hline
\end{tabular}

\section{Table 3: Characteristics of the restricted tendering}

The procedure of the restricted tender-

ing is as follows:

- announcing the intention of invitation to tender along with description of the object to be commissioned (public announcement of a commission),

- expressing interest by potential contractors (applying to be allowed to tender and a statement of fulfilling the tender conditions),

- verification of the applications,

- possibility of presentation of the enteprises applying to be included on the list of bidders,

- listing the enterprises which the customer invites to tender,

- invitation to tender,

- tender preparation,
- submission of tenders along with payment of a deposit (if required),

- public tender opening and giving the basic information about the tender and the bidder,

- tender validity verification by the customer,

- assessment of valid tenders,

- selecting the most profitable tender by the customer or annulment of the invitation to tender (informing all bidders about this decision),

- payment of the guarantee of proper contract fulfilment by the chosen bidder,

- contract signing (following the period allowed for possible protests or complaints). 
Tender documents and

\section{procedure}

Tender documents in the case of con-

struction work is as follows:

- specification of essential terms of the contract,

- preliminary list of tasks (the number of tasks calculated on the basis of the construction project documents),

- the construction project documents,

- technical specification,

- a sample construction contract,

- samples of the required declarations (e.g. stating that the contractor has appropriate employees or equipment).

The basic content of the tender notice and the specification of essential terms of the contract are presented in Table 4.

\section{The form of the deposit:}

The customer determines the amount of the deposit, not higher than $3 \%$ of the commission value.

The deposit may be paid in one or several forms, such as:

1) money,

2) bank bonds or bonds obtained from co-operative savings and credit unions (but the latter are always cash guarantees),

3) bank guarantees,

4) insurance guarantees,

5) bonds issued by subjects. The deposit is submitted before the tender deadline. The deposit is returned to all contractors after the choice of the best offer or the annulment of the procedure with the exception of the contractor whose offer has been accepted (with whom

The content of the tender notice should be as follows:

Specification of essential terms of the contract contains at least the following:

- the name and address of the customer,

- the subject (the kind and number of tasks involved),

- when and where the construction is to be performed,

- the kind of tender,

- when and where the opening of tenders is to take place,

- when and where the documents are available,

- when and where the tenders are to be submitted,

- the deposit,

- the criteria of assessment of tenders and their weight. the contract is signed and who pays the financial security of the proper contract performance).

Public opening of tenders:

- information about the amount that the customer has planned for the project performance,

- giving the basic information on the tender and tenderers,

- the tenderers' names and addresses,

- the tenders submitted, e.g. the price, the deadline, etc.,

- administrative information.

\section{Checking tenders:}

- checking validity of the tenders:

- whether the documents are complete,

- whether the calculations are correct,

- whether the tenders are in accordance with the specification of essential terms of the contract and with legal regulations (such as the public procurement law),

\section{Choosing the best offer:}

calculating the best balance of the price and other criteria.

The most advantageous offer is either the one which has the most advantageous balance of the price and other criteria related to the object of the tender or the one which offers the lowest price (if the price was the only criterion).

\section{Sample tender assessment criteria:}

price,

- deadline,

- guarantee of quality (years),

- payment conditions (e.g. invoice payment postponement date),

- functionality(parameters),

- ecology(parameters).

The formula for converting the partial assessments into the final assessment (in case, the most favourable value is the lowest in tender) is as follows:

Table 4: The content of the tender notice and the specification of essential terms of the contract 


$$
\mathrm{P}_{\mathrm{x}}=\sum \mathrm{P}_{\mathrm{xi}=} \sum\left(\mathrm{K}_{\min } / \mathrm{K}_{\mathrm{xi}}\right) \bullet \mathrm{w}_{\mathrm{i}}(1)
$$

where:

$$
\begin{aligned}
& \mathrm{P}_{\mathrm{x}} \text { - the final assessment granted to } \\
& \text { tender " } \mathrm{x} \text { " }
\end{aligned}
$$$$
\mathrm{P}_{\mathrm{xi}} \text { - the partial assessment granted to }
$$$$
\text { tender " } x \text { " according to criterion " } i \text { " }
$$$$
\mathrm{K}_{\min } \text { - the most advantageous value }
$$$$
\text { given in tenders among all tenders }
$$$$
\text { according to a given criterion, e.g. }
$$$$
\text { the tender gross price which is the }
$$$$
\text { lowest among the prices given in all }
$$
tenders, the shortest deadline;
$\mathrm{K}_{\mathrm{xi}}$ - the value given in tender " $\mathrm{x}$ " according to a given criterion (another offer), e.g. the gross tender price given in tender " $x$ ", the proposed

\section{Mistakes made by customers.}

This chapter discusses the most common mistakes made by customers applying the public procurement procedure on the basis of interviews held with representatives of communes dealing with public procurement and with contractors taking part in the public procurement procedure and on the basis of available public procurement documentation, with its scope of attention being limited to two basic modes of public procurement in the building industry: open tendering and restricted tendering.

The most common mistakes made by customers who apply the public

\begin{tabular}{|c|c|c|}
\hline Type of mistake & Description of mistake & Problems, consequences \\
\hline An incorrect cost estimate of the last order & $\begin{array}{l}\text { A mistake resulting from a lack of detailed } \\
\text { recognition of the subject of order. The } \\
\text { customer did not analyze the scope of } \\
\text { documentation in detail and did not } \\
\text { become familiar with the conditions in the } \\
\text { field, did not predict difficulties that may } \\
\text { arise during the constructing this structure, } \\
\text { did not become familiar with the technology } \\
\text { expected to be used in the documentation. } \\
\text { An incorrect assessment of construction } \\
\text { materials used during construction. }\end{array}$ & $\begin{array}{l}\text { The means the customer intends to allocate } \\
\text { for the construction of the subject of order } \\
\text { are insufficient. } \\
\text { In the case of territorial self-government, } \\
\text { the completion of the investment is planned } \\
\text { according to the budget and the financial } \\
\text { means are protected by law. In the case } \\
\text { when the value given in the offer exceeds } \\
\text { the amount of means available to the } \\
\text { customer and he will not be able to increase } \\
\text { this amount - annulment of proceedings. }\end{array}$ \\
\hline $\begin{array}{l}\text { The subject of order had not been described } \\
\text { in detail. }\end{array}$ & $\begin{array}{l}\text { When describing the subject of order, the } \\
\text { customer did not describe the exact scope. } \\
\text { The customer did not present all documents } \\
\text { related to the project, did not give all the } \\
\text { preliminary measurements of works, etc. }\end{array}$ & $\begin{array}{l}\text { The contractor presented a tender offer } \\
\text { which may have not included the whole } \\
\text { subject of order. } \\
\text { A contractor who verifies the documents } \\
\text { related to the project may not notice } \\
\text { the customer's mistake. In this case the } \\
\text { customer will be forced to give consent } \\
\text { to the construction works or to announce } \\
\text { following proceedings to complete the } \\
\text { scope of work which had not been described } \\
\text { in the proper proceedings. }\end{array}$ \\
\hline $\begin{array}{l}\text { The expression 'or equivalent' are } \\
\text { constantly not used while describing the } \\
\text { subject of order and its completion (when } \\
\text { describing used materials for example). In } \\
\text { the field of construction designers and cost } \\
\text { evaluators often use this expression. }\end{array}$ & $\begin{array}{l}\text { In this case the customer assumes } \\
\text { the solutions that he has given are } \\
\text { the exemplary ones and that they are } \\
\text { impossible to change. }\end{array}$ & $\begin{array}{l}\text { Pointing out specific materials and specific } \\
\text { producers while completing the order is a } \\
\text { lack of observance of the principle of fair } \\
\text { treatment of all contractors. } \\
\text { The customer may act to his own detriment, } \\
\text { as the equivalent solutions may be better } \\
\text { or the same as the ones he had picked, and } \\
\text { they may also be cheaper. A consequence } \\
\text { of such action may be an appeal to or a } \\
\text { annulment of proceedings. }\end{array}$ \\
\hline
\end{tabular}
procurement procedure and problems related to the consequences of these mistakes are presented in the following tables 5,6,7.

\section{Table 5: Mistakes pertaining to the subject of order}


A general description of terms and conditions of applying for public procurement and requesting documents confirming their fulfillment at the same time.
Description of mistake

The customer does not specify exactly what conditions must be met by the contractor in order to apply for public procurement. E.g. in order for the contractor to confirm that he has the necessary expertise and experience, the customer requested a list of construction works. He did not specify what works will be completed and how much they will cost.

Example. The subject of order is a warehouse with the area of $1500 \mathrm{~m}^{2}$ and cubic capacity of $5000 \mathrm{~m}^{3}$. The value of the order amounts to $2 \mathrm{MIn}$ PLN. The customer gives very difficult to meet conditions of participation in proceedings: in order to fulfill the condition of presenting sufficient knowledge and expertise, the contractor must prove that during the course of the last 5 years he has completed a civil structure with the area of $3000 \mathrm{~m}^{2}$, cubic capacity of $10000 \mathrm{~m}^{3}$ and value of PLN 4 Mln. The customer gives very low conditions that must be fulfilled in order to take part in the proceedings: the contractor shall prove that he has built a detached house

Expressing conditions in such a way that only one or a group of contractors can fulfill them is a mistake of the customer. The customer shall not specify the conditions too strictly, for example by writing that a contractor may not get public procurement unless he presents that he has completed a civil structure with the cubic capacity of $3000 \mathrm{~m}^{3}$ and the value of PLN 4 Mln.
Problems, consequences

The contractor does not know exactly what conditions he should fulfill and presents the wrong documents. By making this mistake, the customer exposes himself to appeals and an annulment of proceedings, since incorrect offers may have been presented. The conditions must be described in detail, in case they were described only in general terms, the only thing that may be asked for is a declaration of fulfillment of conditions.

The conditions that the constructor must fulfill must correspond to the subject of order, proportions must be met. If the conditions specified by customers to take part in proceedings are too high, they are risking that no contractors will take part in the.offfer On the other hand, if the conditions specified by customers to take part in proceedings are too low, there is a risk that undesirable contractors will take part in the tender and that they will have problems with the completion of the task. A consequence of such a mistake made by the customer may be an appeal to or a annulment of proceedings.

If the customer behaves this way, he will only offer public procurement to a contractor who has completed a civil structure with the cubic capacity of $3000 \mathrm{~m}^{3}$ and the value of PLN 4 Mln.

A consequence of such a mistake made by the customer may be appeals or a annulment of proceedings. Conditions and chances must be the same for all contractors in order for principles of fair competition to be maintained.

Table 6: Mistakes regarding the terms and conditions of taking part in proceedings.

Most errors and problems presented in Tables 5-7 result from the hasty, careless and ill-considered preparation of the tender, the inaccurate reading, elaboration and preparation of necessary documents and the lack of acquaintance with current legal provisions concerning public procurement. When reasons of these errors are eliminated, there will be a higher chance that the public procurement procedure will be carried out correctly and without problems and there will be no appeals on the part of tenderers or invalidation of the procedure.

\section{Conclusions}

The article describes the public procurement procedure in the field of construction in Poland which is limited to two basic modes of tender. The most common mistakes made by customers related to the implementation of this procedure had also been presented.

The tender procedure had been clearly presented in the article in points and table listings. Aspects pertaining to problems and the reasons why mistakes had been made by customers. These mistakes are mainly related to the subject of order, concern the conditions of partici- pation in the proceedings and the specification of essential terms of the contract. They result from the hasty, careless and ill-considered preparation of the tender, the inaccurate reading, elaboration and preparation of necessary documents and the lack of acquaintance with current legal provisions concerning public procurement. Consequences of these mistakes may be appeals and annulment of proceedings.

The presentation of the problem in points and tabular forms may be useful for the comparison of the tender procedure and related problems in other countries, too. 


\begin{tabular}{|c|c|c|}
\hline Type of mistake & Description of mistake & Problems, consequences \\
\hline $\begin{array}{l}\text { The terms and conditions of participation } \\
\text { in proceedings are different from the ones } \\
\text { in the specification of essential terms of } \\
\text { the contract, from the announcement of } \\
\text { the order and from the declaration form of } \\
\text { tender. }\end{array}$ & $\begin{array}{l}\text { Example: In the proceedings, the customer } \\
\text { stipulated the following condition in the } \\
\text { specification and in the announcement of } \\
\text { the order: the contractor shall present that } \\
\text { he had completed a civil structure with } \\
\text { the cubic capacity of } 3000 \mathrm{~m}^{3} \text { but in the } \\
\text { declaration form of the tender offer he wrote } \\
\text { a cubic capacity of } 3500 \mathrm{~m}^{3} \text {. }\end{array}$ & $\begin{array}{l}\text { A lack of consistency of conditions in } \\
\text { various documents. The contractor does not } \\
\text { know what conditions he shall fulfill. } \\
\text { If he has written that he had completed a } \\
\text { civil structure with the capacity of } 300 \mathrm{~m}^{3} \\
\text { instead of } 3500 \mathrm{~m}^{3} \text { his tender offer will } \\
\text { be rejected. The customer will also have } \\
\text { a problem with the assessment of these } \\
\text { tender offers. By making such a mistake, the } \\
\text { customer is risking appeals or an annulment } \\
\text { of proceedings. }\end{array}$ \\
\hline $\begin{array}{l}\text { Changes in the content of specification of } \\
\text { essential terms of the contract. }\end{array}$ & $\begin{array}{l}\text { Changes made to the content of } \\
\text { specification, e.g. changes in the conditions } \\
\text { of participation in proceedings without } \\
\text { changes being made to the announcement } \\
\text { of proceedings. }\end{array}$ & $\begin{array}{l}\text { Incoherence between the specification } \\
\text { and the announcement - annulment of } \\
\text { proceedings }\end{array}$ \\
\hline $\begin{array}{l}\text { A lack of stipulation of terms and conditions } \\
\text { of taking part in the proceedings }\end{array}$ & $\begin{array}{l}\text { The customer demands specific documents } \\
\text { from contractors without prior stipulation of } \\
\text { the terms and conditions of proceedings. }\end{array}$ & $\begin{array}{l}\text { The purpose of attaching documents to the } \\
\text { tender offer is, among others, to assess } \\
\text { if the conditions of participation have } \\
\text { been met. First, these conditions must be } \\
\text { specified and then documents proving } \\
\text { their fulfillment shall be required. The } \\
\text { consequences of this mistake are appeals } \\
\text { or a annulment of proceedings. }\end{array}$ \\
\hline $\begin{array}{l}\text { Not answering the customer's questions } \\
\text { concerning the content of specification of } \\
\text { essential terms of the contract on time. }\end{array}$ & $\begin{array}{l}\text { The questions addressed and sent to } \\
\text { the customer may have a significant } \\
\text { impact on the preparation of tender } \\
\text { offers by contractors and on the course of } \\
\text { proceedings. }\end{array}$ & $\begin{array}{l}\text { The contractors submit tender offers which } \\
\text { contain mistakes. The customer must ask } \\
\text { the contractors for supplementations and } \\
\text { explanations. A consequence of such a } \\
\text { mistake made by the customer may be } \\
\text { appeals or an annulment of proceedings. }\end{array}$ \\
\hline $\begin{array}{l}\text { The contractors' questions together with the } \\
\text { customer's replies to these questions are } \\
\text { not posted on the Web page. }\end{array}$ & $\begin{array}{l}\text { By doing this, the customer informs only } \\
\text { the contractors that he knows and who have } \\
\text { received the specification and have asked } \\
\text { questions. }\end{array}$ & $\begin{array}{l}\text { Not all contractors get the chance to become } \\
\text { informed. } \\
\text { A consequence of such a mistake made } \\
\text { by the customer may be appeals or a } \\
\text { annulment of proceedings. }\end{array}$ \\
\hline
\end{tabular}

\section{Table 7: Mistakes regarding the specification of essential terms of the contract.}

\section{References}

Act of 29, (2004) - Public Procurement Law Journal of Laws of 2010, No. 113, item. 759; No. 161, item. 1078 and No. 182, item 1228 and of 2011, No. 5, item 13 and No. 28, item 143) - consolidated text prepared by the Public Procurement Office OPM, (2009) Ordinance of the Prime Minister of 23 December 2009 regarding values of orders and competitions upon which the obligation to submit notices to the Office for Official Publications of the European Communities is conditional Journal of Laws from 2009, No.224, item 1795), (in polish)

Radziszewska-Zielina, E. (2007), Analysis of construction companies taking part in public orders system, Zeszyty Naukowe
Politechniki Gdańskiej (Research Bulletin of the Technical University of Gdańsk), Vol. 61, pp. 39-44, (in polish)

Wysocki, J. (2009), Most common mistakes in specification of essential terms of the contract, Presscom, Wroctaw, (in polish). www.uzp.gov.pl - Public Procurement Office 